\title{
Pengaruh Personal Background dan Pengetahuan Dewan Tentang Anggaran Terhadap Kinerja DPRD Kota Padang Dalam Pengawasan Keuangan Daerah
}

\section{The Influence of Personal Background and Council Budget Knowledge toward the Performance of DPRD Padang City on Region Financial Control}

\author{
Imelda Sari \\ Prodi Akuntansi, Fakultas Ekonomi Universitas YARSI \\ E-mail: imelda.sari@yarsi.ac.id
}

KEYWORDS Personal Background, Council Budget Knowledge, and Performance of DPRD on Region Financial Control

ABSTRACT This research aims to examine the influence of personal background, and council budget knowledge toward the performance of DPRD on region financial control. A controlling from the legislative board in the local economic policy execution is an important thing to realize the right regional financial management. The population of research is 45 members of DPRD Padang City. The entire community in this study serves as the sample with the census method. The data consist of primary data that taken from questionnaires distributed directly to respondents. The analyze method used in this study is multiple regression linear model, using $F$ test, and $t$ test is simultaneously and partially applied. The result of this research and hypothesis testing shows that simultaneously personal background and council budget knowledge had the significant influence on the performance of DPRD on region financial control. Partially, indicators of personal background have no significant impact on the performance of DPRD on region financial control. Variables of council budget knowledge also have no influences toward the achievement of DPRD on region financial control. One of indicators council budget knowledge has positive and significant influence toward the performance of DPRD on region financial control is training about region financial control.

\section{PENDAHULUAN}

Otonomi Daerah bukanlah merupakan suatu kebijakan yang baru dalam penyelenggaraan pemerintahan di Indonesia karena sejak berdirinya negara kesatuan Republik Indonesia sudah dikenal adanya otonomi daerah yang dipayungi oleh Pasal 18 Undang-Undang Dasar 1945 (Syamsudin, 2005). Sedangkan inti dari pelaksanaan otonomi daerah adalah terdapatnya keleluasaan pemerintah daerah (discretionary power) untuk menyelenggarakan pemerintahan sendiri atas dasar prakarsa, kreativitas, dan peran serta masyarakat dalam rangka mengembangkan dan memajukan daerahnya.

Perubahan penyelenggaraan pemerintahan daerah juga ditandai dengan diberlakukannya Undang-Undang Nomor 32 Tahun 2004 tentang Pemerintahan 
Daerah dan Undang-Undang No. 33 Tahun 2004 tentang Perimbangan Keuangan antara Pemerintah Pusat dan Pemerintah Daerah, yang telah membawa perubahan fundamental dalam sistem Pemerintahan Daerah, yaitu dari sistem pemerintahan yang sentralistik kepada desentralisasi.

\section{Undang-Undang Nomor 32 Tahun}

2004 tentang Pemerintah Daerah menempatkan Pemerintah Daerah dan DPRD selaku penyelenggara pemerintahan daerah. Sesama unsur pemerintahan daerah pada dasarnya kedudukan Pemerintah Daerah (eksekutif) dan DPRD (legislatif) adalah sama, yang membedakannya adalah fungsi, tugas dan wewenang serta hak dan kewajibannya. Dalam hal pengelolaan keuangan daerah, pada tahap perencanaan pemerintah daerah dan DPRD duduk bersama-sama sebagai mitra untuk merumuskan suatu kebijakan mengenai rencana anggaran pendapatan dan belanja daerah. Kemudian setelah rencana anggaran tersebut disahkan menjadi APBD, pemerintah daerah yang akan melaksanakan pengelolaan dari APBD tersebut. Untuk mewujudkan pengelolaan keuangan daerah yang baik diperlukan pengawasan terhadap pelaksanaan kebijakan keuangan daerah yang dilakukan oleh lembaga legislatif (DPRD).

Selanjutnya di dalam PP No. 58 Tahun 2005 tentang Pengelolaan Keuangan Daerah Pasal 133 menyatakan bahwa Pengawasan pengelolaan keuangan daerah berpedoman pada ketentuan peraturan perundang-undangan. Hal ini berarti bahwa dalam melaksanakan pengawasan terhadap APBD, DPRD harus mengacu kepada peraturan yang berlaku. Hal ini juga mengindikasikan bahwa anggota dewan harus mempunyai pengetahuan yang cukup mengenai anggaran. Ketika sedang melaksanakan fungsi pengawasan di bidang anggaran anggota dewan sekurangkurangnya harus mengetahui undangundang atau peraturan apa saja yang mengatur mengenai anggaran tersebut. Sehingga anggota dewan tersebut dapat mengetahui apakah pelaksanaan anggaran telah sesuai dengan peraturan perundangan yang ditetapkan atau tidak. Tidak hanya sebatas itu saja, anggota dewan juga harus memiliki kompetensi dalam hal proses anggaran dan teknis pengawasan anggaran. Kesan selama ini yang memposisikan eksekutif/pemerintah daerah lebih kuat dalam hal memahami proses anggaran seperti tak terbantahkan khususnya di awal reformasi. Sejauh ini masih banyak anggota dewan yang bingung membedakan terminologi antara pengawasan, pengendalian dan pemeriksaan. Hal ini mengindikasikan masih lemahnya pemahaman dewan mengenai anggaran. Pengetahuan dewan tentang anggaran ini sangat berperan penting dalam meningkatkan kinerja DPRD dalam melaksanakan fungsi pengawasan di bidang anggaran.

Selain itu peran lembaga eksekutif terus meningkat bagi pelayanan publik (public service) secara efektif dan efisien dalam pengelolaan keuangan daerah. Hal ini tentunya juga akan menuntut kinerja yang baik dari legislatif atau DPRD dalam pengawasan keuangan daerah. Untuk mendapatkan kinerja yang baik menuntut sumberdaya manusia yang berkualitas. Salah satu indikator sumberdaya manusia berkualitas adalah tingkat pendidikan. Tingkat pendidikan yang tinggi akan mampu membantu seseorang menyelesaikan tugasnya dengan baik. Kesesuaian latar belakang pendidikan juga berpengaruh dalam kinerja seseorang. Seseorang yang mempunyai latar belakang pendidikan yang sama dengan bidang pekerjaannya cenderung lebih mengerti tentang masalah atau pekerjaan yang sedang dihadapinya. Kualitas sumberdaya manusia juga ditentukan oleh masa kerja atau lamanya menjabat sebagai anggota DPRD bagi para anggota dewan. DPRD akan dapat memainkan perannya dengan baik apabila pimpinan dan anggotaanggotanya memiliki kualifikasi ideal, 
dalam arti memahami benar hak, tugas, wewenang dan fungsinya dan mampu mengaplikasikannya secara baik serta didukung dengan tingkat pendidikan dan pengalaman di bidang politik dan pemerintahan yang memadai (Yudono, 2000).

Studi yang dilakukan Murni dan Witono (2003) yang meneliti pengaruh personal background dan political background terhadap peran DPRD dalam pengawasan keuangan daerah menunjukkan bahwa strata pendidikan, latar belakang pekerjaan dan asal parpol berpengaruh signifikan terhadap pengawasan keuangan daerah. Sedangkan jenis kelamin, usia, bidang pendidikan, pengalaman politik, pengalaman di DPRD, ideologi parpol, dan asal komisi tidak berpengaruh secara signifikan.

Indriani (2002) meneliti pengaruh pengetahuan dan RPPs terhadap peranan DPRD dalam pengawasan keuangan daerah. Hasil penelitiannnya menyatakan bahwa pengetahuan berpengaruh terhadap peranan DPRD dalam pengawasan keuangan daerah.

Dewan Perwakilan Rakyat Daerah masa bakti 2009-2014 merupakan wakil rakyat di daerah hasil pemilu ketiga setelah masa reformasi. Dibandingkan dengan pemilu diawal masa reformasi, hasil pemilu 2009 ini dapat dikatakan melewati proses demokratisasi yang lebih matang. Perkembangan demokrasi yang Indonesia yang makin matang ini pulalah yang mendorong adanya tuntutan kepada anggota DPRD untuk meningkatkan kinerja dan kualitasnya. Namun permasalahannya, pada kenyataannya tuntutan tersebut juga harus dihadapkan pada kondisi faktual bahwa sebagian besar anggota DPRD periode ini didominasi oleh wajah baru, yang dipilih dan diangkat dari partai-partai pemenang pemilu yang mempunyai latar belakang pendidikan dan pekerjaan yang berbeda sebelum menjadi anggota DPRD. Sehingga ketika mereka dipilih menjadi anggota dewan, keterbatasan pengetahuan dan pengalaman ini akan menjadi kendala dalam melaksanakan fungsi pengawasan. Hal ini memerlukan waktu yang relatif lebih banyak untuk memahami dan mendalami tugas serta wewenangnya dalam menjalani peran sebagai wakil rakyat

Hal ini juga yang menyebabkan terjadinya permasalahan dan kelemahan dalam pengelolaan keuangan daerah dari aspek lembaga legislatif yaitu masih rendahnya peran DPRD dalam keseluruhan proses atau siklus anggaran mulai dari perencanaan, pelaksanaan, pelaporan maupun pengawasan program kerja eksekutif. Akibatnya banyak terjadi sejumlah masalah penyimpangan anggaran di pemerintah daerah. Sebagai contoh penyelewengan terhadap APBD yang dilakukan oleh DPRD Kota Padang yang pada tahap perencanaan anggaran para pimpinan dan anggota dewan telah memasukan sejumlah pos pengeluaran yang tidak sesuai peraturan dan ditujukan untuk memperkaya diri sendiri sehingga mengakibatkan kerugian terhadap keuangan daerah.

Berdasarkan penjelasan diatas lemahnya fungsi pengawasan Legislatif merupakan faktor yang mempengaruhi kinerja Legislatif terhadap Eksekutif. Kelemahan yang terjadi atas kinerja legislatif dalam pengawasan keuangan daerah dapat mungkin terjadi karena kelemahan sistem politiknya atau pun individu sebagai pelaku politik dalam hal ini adalah kualitas sumber daya manusia yang dimiliki oleh DPRD selaku pengawas pelaksanaan keuangan daerah. Penelitian ini bertujuan mengetahui pengaruh personal background anggota DPRD dan pengetahuan anggota dewan tentang anggaran terhadap kinerja DPRD dalam pengawasan keuangan daerah.

\section{METODOLOGI}

Peneliti menggunakan desain penelitian kausal untuk menganalisis bagaimana suatu variabel mempengaruhi 
variabel lain, dan melihat dampaknya pada variabel dependen secara langsung. Lokasi penelitian pada Lembaga DPRD Kota Padang. Jangka waktu penelitian dimulai dari bulan Desember 2009 sampai Februari 2010. Populasi penelitian ini adalah seluruh anggota DPRD kota Padang sebanyak 45 orang, pengambilan sampel dilakukan dengan metode sensus dimana seluruh populasi dijadikan sampel. Sampel yang diambil adalah seluruh anggota dewan yang ada pada DPRD Kota Padang sebanyak 45 orang. Variabel operasional yang dipakai dalam penelitian ini dapat dilihat pada Tabel 1.

Tabel 1. Variabel Operasional

\begin{tabular}{|c|c|c|}
\hline Variabel & Indikator & Skala \\
\hline $\begin{array}{l}\text { Kinerja } \\
\text { DPRD } \\
\text { dalam } \\
\text { Pengawasan } \\
\text { Keuangan } \\
\text { Daerah (Y) }\end{array}$ & $\begin{array}{lr}\text { - } \begin{array}{l}\text { Keaktifan } \\
\text { dewan anggota } \\
\text { dalam }\end{array} \\
\text { menghadiri } & \text { sidang } \\
\text { paripurna } & \\
\text { - Memahami dan } \\
\text { menguasai seluruh } \\
\text { proses struktur } \\
\text { anggaran } \\
\text { - Keaktifan dalam } \\
\text { melakukan } \\
\text { kunjungan kerja } \\
\text { dalam rangka } \\
\text { fungsi pengawasan }\end{array}$ & Interval \\
\hline $\begin{array}{l}\text { Personal } \\
\text { Background } \\
\text { (X1) }\end{array}$ & $\begin{array}{lr}\text { Latar belakang diri } \\
\text { anggota dewan yang } \\
\text { meliputi : } & \text { jenis } \\
\text { kelamin, usia, } & \text { tingkat } \\
\text { pendidikan, } & \text { bidang } \\
\text { pendidikan, } & \text { dan } \\
\text { pekerjaan } & \text { sebelum } \\
\text { menjadi } & \text { anggota } \\
\text { dewan } & \end{array}$ & Nominal \\
\hline $\begin{array}{l}\text { Pengetahuan } \\
\text { Dewan } \\
\text { Tentang } \\
\text { anggaran }\end{array}$ & $\begin{array}{l}\text { - Pelatihan/seminar } \\
\text { keuangan daerah } \\
\text { yang pernah diikuti } \\
\text { anggota Dewan } \\
\text { - Pelatihan/seminar } \\
\text { Pengawasan } \\
\text { Keuangan Daerah } \\
\text { yang pernah diikuti } \\
\text { anggota dewan } \\
\text { - Pengetahuan } \\
\text { terhadap peraturan } \\
\text { dan perundang- } \\
\text { undangan keuangan } \\
\text { daerah }\end{array}$ & Interval \\
\hline
\end{tabular}

Uji Kualitas Data dalam penelitian ini dilakukan dengan menggunakan uji asumsi klasik yang terdiri dari Uji validitas, Uji Reliabilitas, Uji Normalitas, Uji Multikolinearitas dan uji Heteroskedastisitas.
Teknik pengumpulan data dalam dengan menggunakan kuesioner dan jenis data adalah data primer. Kuesioner diberikan kepada seluruh anggota DPRD Kota Padang. Pertanyaan yang ada didalam kuesioner berhubungan dengan indikator dalam penelitian ini, kuesioner ini menggunakan skala likert dengan skor sebagai berikut: angka 5 (sangat setuju), 4 (setuju), 3 (netral), 2 (tidak setuju) dan angka 1 (sangat tidak setuju).

Model dan teknik analisa data penelitian menggunakan pendekatan regresi linear berganda. Model analisa regresi linear berganda dalam penelitian ini dapat dirumuskan sebagai berikut : $\mathrm{Y}=\mathrm{a}+\mathrm{b} 1 \mathrm{X} 1.1+\mathrm{b} 2 \mathrm{X} 1.2+\mathrm{b} 3 \mathrm{X} 1.3+\mathrm{b} 4 \mathrm{X} 1.4+\mathrm{b}$ $5 \mathrm{X} 1.5+\mathrm{b} 6 \mathrm{X} 2.1+\mathrm{b} 7 \mathrm{X} 2.2+\mathrm{b} 8 \mathrm{X} 2.3+\mathrm{e}$

\section{Dimana :}

$\mathrm{Y}=$ Kinerja DPRD Pengawasan Keuangan Daerah (APBD)

$\mathrm{a}=$ Konstansta

b1-b8 = Koefisien regresi

$\mathrm{X} 1.1=$ Personal Background (Jenis Kelamin)

$\mathrm{X} 1.2=$ Personal Background (Umur)

$\mathrm{X} 1.3=$ Personal Background (Tingkat Pendidikan)

X1.4 = Personal Background (Bidang Pendidikan)

$\mathrm{X} 1.5=$ Personal Background (Pekerjaan sebelum menjadi anggota dewan)

$\mathrm{X} 2.1=$ Pengetahuan Dewan tentang Anggaran (Pelatihan Keuangan Daerah)

$\mathrm{X} 2.2=$ Pengetahuan Dewan tentang Anggaran (Pelatihan Pengawasan Keuangan Daerah)

X3.3 = Pengetahuan Dewan tentang Anggaran (Pengetahuan terhadap $\mathrm{e}=$ Error term Peraturan/UU Keuangan Daerah)

Untuk menguji ada tidaknya pengaruh dari variabel bebas secara menyeluruh terhadap variabel terikat dilakukan dengan menggunakan uji F. Uji ini menggunakan $\quad \alpha 5 \%$. Dengan ketentuan, jika Fhitung > dari Ftabel maka hipotesis yang diajukan dapat diterima atau dapat dinilai berdasarkan hasil uji hipotesis yang ditunjukkan oleh tabel 
koefisien pada kolom signifikansi, yang menunjukkan nilai $<\alpha 5 \%$. Selanjutnya dilakukan pula penilaian setiap variabel bebas yang dilakukan untuk melihat variabel apa yang memberikan pengaruh paling dominan diantara variabel yang ada. Pengujian dilakukan dengan uji $\mathrm{t}$ atau sering disebut uji parsial. Tingkat pengaruh yang signifikan juga didasarkan pada $\alpha 5 \%$. Atau melihat nilai t hitung harus lebih besar dari t tabel. Sebaliknya jika thitung < dari t tabel maka pengaruh yang terjadi tidak signifikan.

\section{ISI}

\section{Pengumpulan Data}

Setelah dilakukan penyebaran kuesioner kepada 45 anggota DPRD Kota Padang, maka diperoleh hasil yang dirangkum pada Tabel 2.

Tabel 2. Data Demografi Responden

\begin{tabular}{|c|c|c|c|}
\hline & Keterangan & Jumlah & Persentase \\
\hline Jenis & - Laki-laki & 42 & $93.3 \%$ \\
\hline Kelamin & - Perempuan & 3 & $6.7 \%$ \\
\hline \multirow[t]{4}{*}{ Usia } & - 21-30 tahun & 1 & $2.2 \%$ \\
\hline & - $31-40$ tahun & 6 & $13.3 \%$ \\
\hline & - 41-50 tahun & 12 & $26.7 \%$ \\
\hline & - > 50 tahun & 26 & $57.8 \%$ \\
\hline \multirow[t]{4}{*}{ Pendidikan } & - SLTA/Sederajat & 3 & $6.7 \%$ \\
\hline & - D3 & 5 & $11.1 \%$ \\
\hline & - $\mathrm{S} 1$ & 22 & $48.9 \%$ \\
\hline & - $\mathrm{S} 2$ & 15 & $33.3 \%$ \\
\hline \multirow{6}{*}{$\begin{array}{l}\text { Bidang } \\
\text { Pendidikan }\end{array}$} & -Ilmu Sospol & 5 & $11,1 \%$ \\
\hline & •Teknik & 8 & $17.8 \%$ \\
\hline & -Ilmu Agama & 5 & $11.1 \%$ \\
\hline & -Akuntansi & 10 & $22.2 \%$ \\
\hline & -Manajemen & 14 & $31.1 \%$ \\
\hline & - lainnya & & $6.7 \%$ \\
\hline \multirow{2}{*}{$\begin{array}{l}\text { Pengalaman } \\
\text { di DPRD }\end{array}$} & - 1 Periode & 33 & $73.3 \%$ \\
\hline & - 2 Periode & 12 & $26.7 \%$ \\
\hline \multirow{4}{*}{$\begin{array}{l}\text { Pekerjaan } \\
\text { sebelum } \\
\text { menjadi } \\
\text { anggota } \\
\text { dewan }\end{array}$} & - Wiraswasta & 25 & $55.6 \%$ \\
\hline & • Karyawan & 10 & $22.2 \%$ \\
\hline & $\begin{array}{l}\text { swasta } \\
\cdot \text { PNS }\end{array}$ & 10 & \\
\hline & & & $22.2 \%$ \\
\hline
\end{tabular}

Data dari Tabel 2 diperoleh hasil bahwa anggota dewan masih didominasi oleh gender laki-laki sebesar 93.3\%, usia anggota dewan minimal adalah 21 tahun yang mana pada penelitian ini responden terbanyak yaitu yang berusia 50 tahun keatas dengan persentase $26 \%$, tingkat pendidikan anggota dewan pada periode ini hampir sebagian besar sudah bergelar sarjana yaitu sekitar $26 \%$ dengan bidang pendidikan yang beragam sekitar $14 \%$ dari bidang manajemen. pada periode ini anggota dewan didominasi oleh wajahwajah baru sekitar 33\% anggota dewan sebelumnya yang belum pernah menjabat sebagai anggota DPRD dengan latar belakang pekerjaan mayoritas dari wiraswasta sebesar $25 \%$.

\section{Analisis Data \\ Pengujian Kualitas Data}

Mengingat pengumpulan data dilakukan dengan menggunakan kuesioner, maka jawaban dari para responden merupakan hal yang penting dalam penelitian. Keabsahan suatu hasil penelitian sosial sangat ditentukan oleh alat ukur yang digunakan. Apabila alat ulur yang digunaka tidak valid, maka hasil penelitian yang diperoleh tidak akan menggambarkan keadaan yang sesungguhnya. Untuk mengatasi hal tersebut, diperlukan dua pengujian yaitu uji validitas (test of validity) dan uji keandalan (test of reliability), untuk menguji kesungguhan jawaban dari responden.

Teknik yang digunakan untuk mengukur validitas pertanyaan atau pernyataan kuesioner adalah Korelasi Product Moment dari Karl Pearson dengan ketentuan : jika $r$ hitung lebih besar dari $r$ tabel, maka skor butir pertanyaan atau pernyataan kuesioner valid tetapi sebaliknya jika $r$ hitung lebih kecil dari $r$ tabel, maka skor butir pertanyaan atau pernyataan kuesioner tidak valid. Sedangkan Teknik yang digunakan untuk mengukur realibilitas pengamatan adalah dengan menggunakan koefisien cronbach alpha, yaitu instrumen dikatakan reliable jika memiliki nilai cronbach alpha lebih besar dari 0,6. Menurut Nunnally (1967) dalam Ghozali (2006) "Suatu konstruk atau variabel dikatakan reliabel jika memberikan nilai cronbach alpha $>0,60$ ". 
Hasil pengujian validitas dengan metode Pearl Correlation menunjukkan bahwa semua pernyataan didalam kuesioner dinyatakan valid. Sedangkan hasil uji reliabilitas menunjukkan bahwa untuk variabel Personal Background memiliki nilai cronbach alpha sebesar 0.81, untuk variabel Pengetahuan Dewan tentang Anggaran 0.825 dan untuk variabel Kinerja DPRD dalam Pengawasan Keuangan Daerah 0.749. hal ini menunjukkan bahwa setiap butir pernyataan didalam kuesioner dapat dikatakan reliabel.

Uji normalitas adalah untuk mengetahui apakah distribusi data mengikuti atau mendekati distribusi normal, menggunakan Uji KolmogorovSmirnov. Kriteria pengujian satu sampel menggunakan pengujian satu sisi yaitu dengan membandingkan probabilitas dengan tingkat signifikansi tertentu yaitu Nilai Signifikan atau probabilitas $<0,05$ maka distribusi data adalah tidak normal. Nilai Signifikan atau probabilitas $>0,05$ maka distribusi data adalah normal. Hasil uji normalitas dengan menggunakan $U j i$ Kolmogorov-Smirnov (Tabel 3) menunjukkan bahwa sebaran data adalah normal dengan nilai Asymp.Sig (2 tailed) adalah 0.542 .

Tabel 3. One-Sample Kolmogorov Smirnov Test

\begin{tabular}{|ll|r|} 
& & \multicolumn{2}{|c|}{ Unstandardized } \\
Normal & $\mathrm{N}$ & 45 \\
Parameters & Mean & .0000000 \\
& Std. & 1.15719863 \\
Most & Deviation & \\
Extreme & Absolute & .119 \\
Differences & Positive & .062 \\
& Negative & -.119 \\
& Kolmogorv- & .801 \\
& Smirnov Z & .542 \\
& Asymp.Sig. & \\
& (2-tailed) & \\
\hline
\end{tabular}

Uji multikolinearitas (Tabel 4) bertujuan untuk menguji, apakah ditemukan atau tidak korelasi diantara variabel independen. Jika terjadi korelasi antar variabel independen maka akan ditemukan adanya masalah multikolinearitas. Uji Multikolinearitas terhadap setiap data variabel bebas yaitu dengan Melihat angka collinearity Statistics yang ditunjukkan oleh Nilai Variance inflation Factor (VIF) dan nilai tolerance. Kriteria agar tidak terjadi multikolinearitas adalah nilai VIF $<5$ dan nilai tolerance $>0.1$ (Santoso,2002). Dari hasil uji multikolinearitas diperoleh nilai VIF untuk variabel Personal Background 1,028 dan nilai tolerance sebesar 0,972. Variabel Pengetahuan Dewan tentang Anggaran nilai VIF 1.057 dan nilai tolerance 0.946 . sehingga dapat disimpulkan bahwa tidak terjadi multikolinearitas dalam model regresi.

Tabel 4. Uji Multikolinearitas

\begin{tabular}{lrc}
\hline & \multicolumn{2}{c}{ Collinearity Statistics } \\
\cline { 2 - 3 } Model & Tolerance & VIF \\
\hline $\begin{array}{l}\text { Personal Background } \\
\text { Pengetahuan Dewan }\end{array}$ & .972 & 1.028 \\
Tentang Anggaran & .946 & 1.057 \\
\end{tabular}

a. Dependent Variable: Kinerja DPRD dalam pengawasan Keuangan Daerah (APBD)

Uji heteroskedastis bertujuan untuk melihat apakah dalam model regresi terjadi ketidaksamaan variabel dari residual satu pengamatan ke pengamatan lain. Model regresi yang baik adalah tidak terjadi heteroskedasitas. Penelitian ini menggunakan metode grafik plot, untuk mendeteksi ada atau tidaknya heteroskedasitas. Metode grafik plot dilakukan dengan cara mendiagnosa diagram residual plot. Residual plot (Studenzized) dibandingkan dengan hasil prediksi. Jika titik-titik sebar membentuk pola tertentu dan teratur bergelombang, melebar kemudian menyempit, maka mengidentifikasikan telah terjadi heteroskedasitas. Berikut adalah grafik plot hasil uji heteroskedastis (Gambar 1).

Dari Gambar 1 di atas terlihat bahwa titik-titik sebaran tidak membentuk pola tertentu dan menyebar secara merata. 
Ini menunjukkan bahwa tidak terjadi heteroskedastisitas.

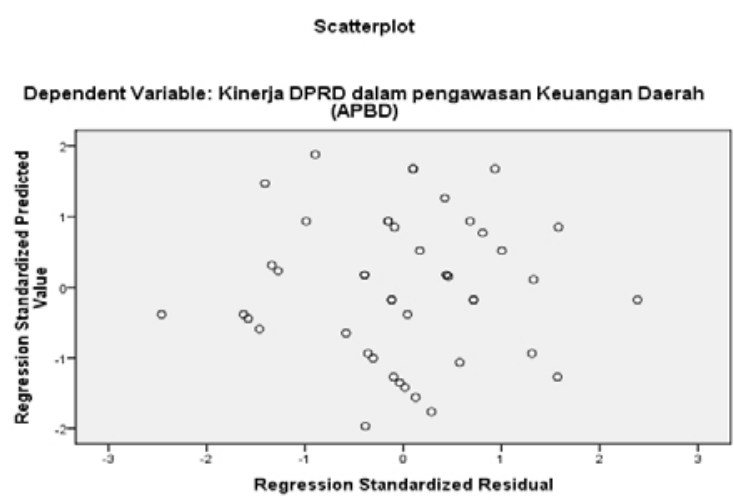

Gambar 1. Diagram Scatterplot

\section{Pengujian Hipotesis}

Dalam penelitian ini pengujian hipotesis dilakukan dengan menggunakan uji simultan (Uji F) dan uji parsial (Uji t). Uji simultan dilakukan untuk mengetahui Pengaruh variabel independen secara bersama-sama terhadap variabel dependen. Uji simultan pada Tabel 5, diperoleh nilai $\mathrm{F}$ hitung sebesar 8.982, $\mathrm{F}$ tabel dengan $\mathrm{n}=$ $2, \mathrm{k}=43$ adalah sebesar 3.21, sehingga dapat disimpulkan bahwa variabel personal background (X1) dan variabel pengetahuan dewan tentang anggaran berpengaruh secara simultan terhadap kinerja DPRD dalam Pengawasan Keuangan Daerah. Hasil uji parsial (uji t) menunjukkan bahwa dari variabel personal background (X1) tidak satu pun indikator yang memiliki pengaruh terhadap kinerja DPRD dalam pengawasan keuangan daerah. Hal ini terbukti dari hasil nilai $\mathrm{t}$ hitung $<\mathrm{t}$ tabel, dan nilai sig. $>0.05$ sehingga dapat diambil kesimpulan bahwa personal background tidak berpengaruh terhadap kinerja DPRD dalam pengawasan keuangan daerah. sementara itu untuk variabel Pengetahuan Dewan tentang Anggaran, dua indikator yaitu indikator pelatihan keuangan daerah dan pengetahuan dewan tentang peraturan/UU Keuangan daerah tidak berpengaruh terhadap kinerja DPRD dalam pengawasan keuangan daerah. Satu indikator yaitu Pelatihan Pengawasan Keuangan Daerah berpengaruh positif signifikan terhadap Kinerja DPRD dalam Pengawasan Keuangan Daerah. Hal ini dibuktikan dengan nilai $\mathrm{t}$ hitung $>\mathrm{t}$ tabel dan nilai sig. $<0,05$ seperti dijelaskan didalam Tabel 6 .

Tabel 5. Hasil Uji Simultan (Uji F)

\begin{tabular}{|l|l|r|c|r|r|r|}
\hline \multicolumn{2}{|l|}{ Model } & $\begin{array}{c}\text { Sum } \\
\text { of } \\
\text { Squar } \\
\text { es }\end{array}$ & $\begin{array}{c}\text { d } \\
\text { f }\end{array}$ & $\begin{array}{c}\text { Mea } \\
\text { n } \\
\text { Squa } \\
\text { re }\end{array}$ & F & Sig \\
\hline 1 & $\begin{array}{l}\text { Regressi } \\
\text { on }\end{array}$ & $\begin{array}{r}38.72 \\
4\end{array}$ & 3 & 12.90 & 8.98 & .00 \\
& Residual & $\begin{array}{r}58.92 \\
1\end{array}$ & 4 & 1.437 & & \\
\hline & Total & $\begin{array}{r}97.64 \\
4\end{array}$ & 4 & & & \\
\hline & & & & \\
\hline
\end{tabular}

Tabel 6. Hasil Uji Parsial (Uji t)

$\begin{array}{ccc}\text { Model } & \begin{array}{c}\text { Unstandardi } \\ \text { zed } \\ \text { Coefficient }\end{array} & \begin{array}{c}\text { Standardized } \\ \text { Coefficient }\end{array} \\ & & \\ & \end{array}$

\begin{tabular}{|c|c|c|c|}
\hline \multirow{2}{*}{\multicolumn{4}{|c|}{1 (Constant) }} \\
\hline & & & \\
\hline $\begin{array}{l}\text { Jenis } \\
\text { Kelamin }\end{array}$ & -0.429 & -0.416 & 0.680 \\
\hline Umur & -0.026 & -0.522 & 0.605 \\
\hline $\begin{array}{l}\text { Tk. } \\
\text { Pendidikan }\end{array}$ & -0.069 & -0.488 & 0.629 \\
\hline $\begin{array}{l}\text { Bid. } \\
\text { Pendidikan }\end{array}$ & 0.0168 & 0.352 & 0.727 \\
\hline Pekerjaan & 0.0845 & 0.741 & 0.465 \\
\hline $\begin{array}{l}\text { Pelatihan } \\
\text { Keu. Daerah }\end{array}$ & 0.203 & 0.862 & 0.395 \\
\hline $\begin{array}{l}\text { Pelatihan } \\
\text { Pengawasan } \\
\text { Keu. Daerah }\end{array}$ & 1.043 & 2.803 & 0.02 \\
\hline $\begin{array}{l}\text { Pengetahuan } \\
\text { Peraturan/U } \\
\text { U Keuangan } \\
\text { Daerah }\end{array}$ & -0.112 & 0.421 & 0.677 \\
\hline
\end{tabular}

Berdasarkan analisis yang telah dilakukan oleh penulis dapat disimpulkan bahwa $\mathrm{H} 1$ ditolak dan $\mathrm{H} 2$ diterima melalui indikator pelatihan pengawasan keuangan daerah. penelitian ini mendapatkan bukti empiris bahwa secara umum variabel personal Background tidak berpengaruh signifikan terhadap kinerja DPRD dalam pengawasan keuangan daerah. 
Hasil penelitian serupa juga pernah dilakukan oleh Winarna dan Murni (2007) yang meneliti tentang pengaruh personal background terhadap peran DPRD dalam pengawasan keuangan daerah. Tidak berpengaruhnya variabel ini dikarenakan konsekuensi tugas yang mengharuskan anggota dewan dari Komisi Keuangan dan Panitia Anggaran membahas dan mengawasi jalannya pengelolaan APBD. Dimana untuk meningkatkan kemampuannya seorang anggota dewan bukan dilihat dari latar belakang diri anggota dewan saja, tetapi pentingnya keikutsertaan anggota dewan dalam seminar-seminar, workshop-workshop, serta pelatihan-pelatihan tentang pengelolaan dan pengawasan keuangan daerah demi meningkatkan kualifikasi yang optimal.

Hal ini sesuai dengan teori yang dikemukakan oleh Hasibuan (2000) mengenai kinerja. menurut Hasibuan Kinerja adalah suatu hasil kerja yang dicapai seseorang dalam melaksanakan tugas-tugas yang dibebankan kepadanya yang didasarkan atas kecakapan, pengalaman, dan kesungguhan serta waktu. jadi dapat disimpulkan bahwa kinerja anggota dewan bukan tergantung sepenuhnya kepada latar belakang diri dari anggota dewan tersebut.

Keikutsertaan anggota dewan dalam berbagai pelatihan pengelolaan dan pengawasan daerah menjadi salah satu Indikator kuat yang mempengaruhi Kinerja DPRD dalam pengawasan keuangan daerah. hasil penelitian ini sependapat dengan hasil penelitian yang telah dilakukan oleh Indriani (2002) yang menyimpulkan bahwa pengetahuan Dewan tentang anggaran berpengaruh secara signifikan terhadap pengawasan keuangan daerah yang dilakukan oleh anggota Dewan. Begitu juga dengan penelitian Sopanah (2003) yang menyatakan pengetahuan Dewan tentang anggaran berpengaruh secara signifikan terhadap pengawasan keuangan daerah baik menurut sampel anggota Dewan maupun masyarakat. Pengetahuan dewan tentang anggaran dapat membantu dalam mendeteksi pemborosan, kebocoran dan kegagalan anggaran

Demi mencapai tingkat fungsional yang memadai maka setiap anggota DPRD harus membenahi diri dan mengkaji ulang posisi dan peranannya sesuai dengan ketentuan perundangan yang berlaku. Selain itu., demi meningkatkan citra DPRD dimasyarakat maka DPRD dituntut untuk bekerja lebih keras dan mempunyai keluaran (output) baik kualitatif maupun kuantitatif memenuhi persyaratan yang ada.

\section{PENUTUP}

Berdasarkan hasil penelitian yang telah dilakukan dapat disimpulkan bahwa variabel personal background tidak berpengaruh secara signifikan terhadap kinerja DPRD dalam pengawasan keuangan daerah. hal ini terbukti dari hasil uji parsial dari masing-masing indikator variabel yang memiliki nilai $\mathrm{t}$ hitung $<\mathrm{t}$ table dan nilai sig $>0.05$. hal ini disebabkan karena latar belakang diri anggota dewan secara personal bukanlah faktor penentu keberhasilan anggota dewan untuk menjalankan tugasnya dalam pengawasan keuangan daerah. Walaupun anggota dewan tersebut memiliki pendidikan yang tinggi, tetapi jika anggota dewan ini tidak mengerti sama sekali tentang prosedur anggaran keuangan daerah tetap saja fungsinya sebagai wakil masyarakat dalam pengawasan keuangan daerah tidak akan berjalan dengan semestinya.

Pengujian berikutnya dilakukan terhadap variabel pengetahuan dewan tentang anggaran. variabel ini terdiri dari 3 indikator yaitu Keikutsertaan anggota dewan dalam pelatihan tentang keuangan daerah, Keikusertaan anggota dewan dalam pelatihan pengawasan keuangan daerah dan pengetahuan anggota dewan tentang peraturan dan undang-undang keuangan daerah. dari 3 indikator tersebut 
hanya 1 indikator yang berpengaruh signifikan secara parsial yaitu indikator keikutsertaan anggota dewan dalam pelatihan pengawasan keuangan daerah.

Untuk kesempurnaan penelitian selanjutnya, maka peneliti selanjutnya dapat menambah Variabel political background seperti asal partai politik, jabatan di partai politik, jumlah partai politik yang pernah diikuti dan daerah pemilihan. Bagi partai politik hendaknya dalam melakukan rekrutmen calon anggota dewan sebagai perwakilannya hendaknya mempertimbangkan dari sisi pengetahuannya. Bagi anggota dewan khususnya komisi yang membidangi keuangan dan sebagai panitia anggaran hendaknya melaksanakan program pemberdayaan bagi para anggota dewan dalam bidang keuangan baik melalui pelatihan, workshop maupun kegiatan lainnya.

\section{DAFTAR PUSTAKA}

Ghozali,Imam, 2006. Aplikasi Analisis Mulivariate dengan Program SPSS, Edisi 4, Badan Penerbit Universitas Diponegoro, Semarang.

Hasibuan, Melayu S.P, 2000. Manajemen Sumber Daya Manusia, Edisi Revisi, Cetakan Kedua, Bumi Aksara, Jakarta

Indriani, Rini. 2002. Pengaruh Pengetahuan dan Rules, Procedures, and Policies (RPPs) terhadap Peranan Dewan Perwakilan Rakyat Daerah (DPRD) dalam Pengawasan Keuangan Daerah (Studi Kasus pada DPRD Kabupaten/Kota Se-Propinsi Bengkulu).Tesis Program Pasca Sarjana UGM Yogyakarta, Tidak Dipublikasikan.

Murni, Sri dan Banu Witono. 2004. Pengaruh Personal Background dan Political Background terhadap
Peranan DPRD dalam Pengawasan Keuangan Daerah. Perspektif, Vol. 9 Nunally. 1967. Psycometric Theory. New York : McGraw-Hill.

Republik Indonesia, 2004. UndangUndang No. 32 Tahun 2004 tentang Pemerintahan Daerah cq. UU No. 12 Tahun 2008 tentang Perubahan Kedua atas UU No. 32 Tahun 2004 tentang Pemerintahan Daerah.

Republik Indonesia, 2004. UndangUndang No. 33 Tahun 2004 tentang Perimbangan Keuangan antara Pemerintah Pusat dan Daerah.

------, Peraturan Pemerintah No. 58 tahun 2005 tentang Pengelolaan Keuangan Daerah

Santoso, Singgih, 2002. Buku Latihan SPSS Statistik Parametrik, Gramedia, Jakarta.

Sopanah. 2003. Pengaruh partisipasi Masyarakat dan Transparansi Kebijakan Publik terhadap Hubungan antara Pengetahuan Dewan tentang Anggaran dengan Pengawasan Keuangan Daerah. Tesis Pascasarjana UGM, Tidak Dipublikasikan.

Syamsudin, Haris, 2005. Desentralisasi dan Otonomi Daerah, LIPI Press, Jakarta.

Winarna, Jaka, dan Sri Murni, 2007. Pengaruh Personal Background, Political Background dan Pengetahuan Dewan tentang Anggaran terhadap Peranan DPRD dalam Pengawasan Keuangan Daerah, Makalah Symposium Nasional Akuntansi X, Unhas Makassar.

Yudono, Bambang, 2002. Peran DPRD dalam Penyelenggaraan Pemerintah Daerah,http://www.bangda.depdagri. go.id/jurnal/jendela3.htm (Diakses bulan Maret 2010), Pustaka Pelajar, Yogyakarta. 